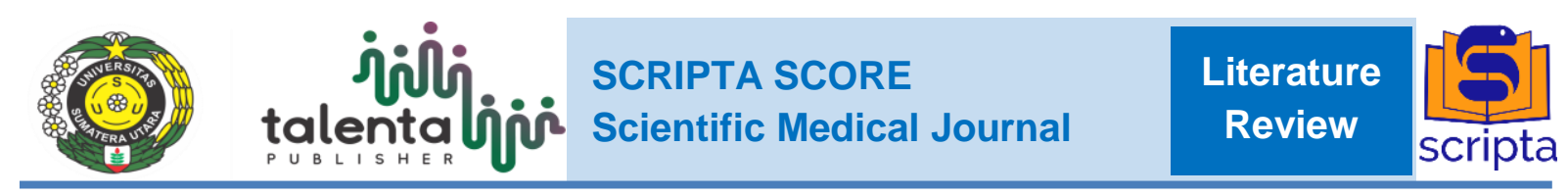

\title{
Cigarettes and Its Effects on Health
}

\author{
Ridwan Balatif ${ }^{1}$ \\ ${ }^{1}$ Faculty of Medicine, Universitas Sumatera Utara, Medan
}

\begin{abstract}
Background: One of the biggest challenges in the world of health is the problem of smoking. In 2018, there was an increase in smokers at the age of $10-18$ years by $9.1 \%$ compared to 2013 , which was $7.2 \%$. It is feared that the increasing number of smokers at a young age will increase the number of noncommunicable diseases (NCD) at a young age. Methods: Writing this article uses the method of literature searching from various sources of information including e-books, websites and search engines. The e-books used contain cigarette information and its effects on health, the websites used are the website of the government and WHO to search for prevalence data and other information, and the search engines used are Google Scholar and Pubmed to search information on cigarette content research and its effects on health. Discussion: The content of cigarettes can cause various side effects in almost all organs of the body. Various studies have found that smoking is a risk factor for NCD. Conclusion: Cessation of smoking can save sufferers and also save people around smokers. When a smoker starts quitting smoking, the body will undergo the process of cleaning up toxic substances of cigarettes that have entered the body.
\end{abstract}

Keywords: cigarette, literature searching, NCD

\section{ABSTRAK}

Latar Belakang: Salah satu tantangan terbesar dalam dunia kesehatan ialah masalah rokok. Pada tahun 2018, terjadi peningkatan perokok pada usia 10-18 tahun sebesar 9,1\% dibandingkan pada tahun 2013 sebesar 7,2\%. Peningkatan jumlah perokok di usia muda ini dikhawatirkan akan meningkatkan jumlah Penyakit Tidak Menular (PTM) di usia muda. Metode: Penulisan artikel ini menggunakan metode pencarian literatur dari berbagai sumber informasi berupa e-book, website dan search engine. E-book yang dipakai memuat informasi rokok dan pengaruhnya kekesehatan, website yang dipakai adalah website pemerintah dan WHO untuk pencarian data prevalensi dan informasi lainnya, dan search engine yang dipakai adalah Google Scholar dan Pubmed untuk pencarian informasi penelitian kandungan rokok dan pengaruhnya kepada kesehatan. Pembahasan: Dari hasil pencarian, kandungan pada rokok dapat menimbulkan berbagai efek samping hampir di seluruh organ tubuh. Berbagai penelitian mendapatkan bahwa kebiasaan merokok merupakan faktor risiko terjadinya PTM. Kesimpulan: Penghentian kebiasaan merokok ini dapat menyelamatkan penderitanya dan juga menyelamatkan orang di sekitar perokok. Ketika seorang perokok mulai berhenti untuk merokok, maka tubuh akan melakukan proses pembersihan dari zat racun pada rokok yang sudah masuk ke dalam tubuh.

Kata kunci: rokok, PTM, pencarian literatur

Received [24 Aug 2019] | Revised [8 May 2020] | Accepted [12 May 2020]

\section{INTRODUCTION}

The problem of smoking is a challenge in the world of health that cannot be denied. Data from the World Health Organization (WHO) estimates that there are 1.1 billion smokers worldwide, $80 \%$ of whom live in countries with lower middle income. ${ }^{[1]}$ In 2018, in Indonesia, there will be an increase in the number of smokers from the age of $10-18$ years, from $7.2 \%$ in 2013 to $9.1 \% .^{[2]}$

It is feared that the increasing number of smokers at a young age will lead to more human resources who are at risk of developing non-communicable diseases (NCDs). Smoking is closely related to the occurrence of various lung diseases. More than $80 \%$ of the incidence of Chronic 
Obstructive Pulmonary Disease (COPD) in the United States is caused by smoking. ${ }^{[3]}$ Also, smoking habits cause other NCDs such as hypertension, stroke, heart disease to cancer.

NCDs incident is closely related to the chemical content contained in cigarettes. Various studies have shown that smoking can be a risk factor for NCDs. It is estimated that smoking increases the risk of coronary heart disease about 2-4 times, stroke 2-4 times, lung cancer 25 times in men, and 25.7 times in women. Besides, smoking can lead to an increased risk of type 2 diabetes mellitus by $30 \%-40 \%$. $^{[4]}$

Side effects from smoking are not only about the smoker (active smoker); people around smokers also get the impact. To prevent this smoking habit, cooperation from various parties, including government, medical staff, the communities, and religious leaders, are needed. This article was written to describe the health effects caused by smoking.

\section{METHODS}

The method for writing this article is through literature searching. Information is sought from various sources, namely from e-books, websites, and search engines. The book used is a book that has a discussion chapter on cigarettes. The site used is the Ministry of Health and WHO (for finding prevalence data and other information). Search engines used are Pubmed and Google Scholar.

\section{DISCUSSION}

\section{Epidemiology of Smoking}

Globally, there has been a decline in the number of smokers over the age of 15 from $23.5 \%$ in 2007 to $20.7 \%$ in 2015 . $^{[5]}$ There are several factors related to the decrease in the prevalence of smokers, namely increases in tobacco taxes and prices, anti-tobacco campaigns, access to services to stop using tobacco, and government regulations regulating tobacco products. ${ }^{[6]}$ The prevalence of smokers in Indonesia has increased from $7.2 \%$ in 2013 to $9.1 \%$ in 2018 in smokers aged $10-18$ years. ${ }^{[2]}$

Every year, more than 7 million deaths are caused by cigarette use, and 1.2 million are non-smokers exposed to cigarette smoke. ${ }^{[1]}$ A smoker's life expectancy is ten years shorter than someone who has never smoked. ${ }^{[7]}$ In reducing the number of smokers in Indonesia, the government seeks to make various health counseling, anti-smoking campaigns, regulate cigarette advertisements, and increase cigarette excise tax by $23 \%$ and retail price by $35 \%{ }^{[8]}$ This effort can help reduce the number of smokers in Indonesia.

\section{Chemical Substances in Cigarettes}

Since 1950, there has been an identification of the chemical components in tobacco. ${ }^{[9]}$ Until now, almost 7,000 chemical compounds have been identified in cigarette smoke. Of the 7,000 chemical compounds, 69 of them are known to be carcinogenic. ${ }^{[10]}$ Carcinogenic compounds are present in cigarette smoke such as acetaldehyde, arsenic, benzene, cadmium, ethylene oxide, formaldehyde, polonium nickel (Figure 1). ${ }^{[11]}$ Smoking is enjoying burned nicotine.

Nicotine is a specific organic compound contained in tobacco leaves. If we smoke nicotine, it will cause psychological stimulation of addiction. In addition to nicotine, the additives, flavoring, and aroma of cigarettes are also formed to fulfill the tastes of consumers (smokers). Currently, several types of cigarettes have been equipped with filters to reduce tar and nicotine levels. ${ }^{[12]}$ Even though you have used a filter, this does not mean that cigarettes will be safe for consumption, as some chemicals can still pass through the filter. Table 1 and Table 2 describe some cigarette compounds that can penetrate and be caught by the filter. 


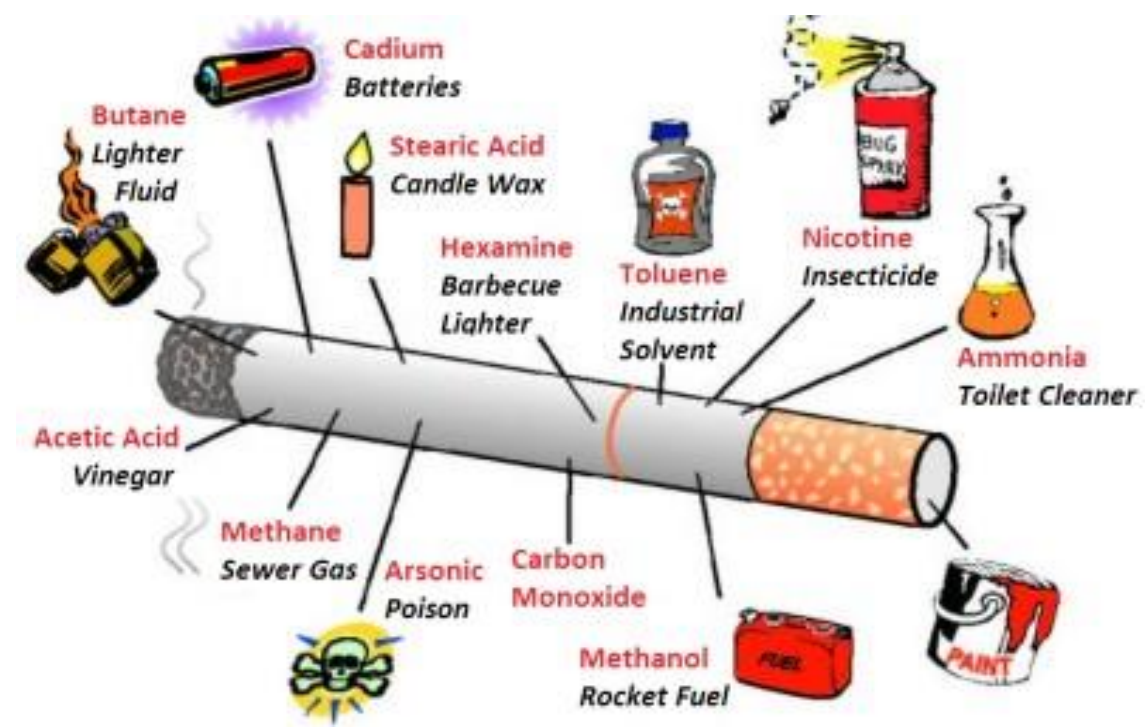

Figure 1. Illustration of the chemical substance in cigarettes ${ }^{[13]}$

Table 1. The main chemical component of smoke caught in Cambridge filters ${ }^{[12]}$

\begin{tabular}{ll}
\multicolumn{1}{c}{ Compound } & \multicolumn{1}{c}{$\boldsymbol{\mu g} /$ cigarette } \\
\hline Nicotine & $100-3000$ \\
Solanesol & $600-1000$ \\
Total nonvolatile HC* & $300-400$ \\
Catechol & $200-400$ \\
Dihydroxybenzenes & $200-400$ \\
Neophytadienes & $200-350$ \\
Benzofuranes & $200-300$ \\
Linoleic acid & $150-250$ \\
Acetic acid & $100-150$ \\
Phenol & $80-160$ \\
Nornikotine & $5-150$ \\
Oleic acid & $40-110$ \\
n-Hentriacontane & 100 \\
Lactic acid & $60-80$ \\
Stearic acid & $50-75$ \\
Cyclones & $40-70$ \\
Limonene & $30-60$ \\
Bipytidils & $10-30$ \\
Scopoletin & $15-30$ \\
Skatole & $12-16$ \\
\hline
\end{tabular}

*HC: Hydrocarbon 
Table 2. The main chemical component of smoke that passes through the Cambridge filter ${ }^{[12]}$

\begin{tabular}{ll}
\hline \multicolumn{1}{c}{ Compound } & \multicolumn{1}{c}{ Concentration/cigarette } \\
\hline Nitrogen & $120-280 \mathrm{mg}$ \\
Oxygen & $50-70 \mathrm{mg}$ \\
Carbon dioxide & $45-65 \mathrm{mg}$ \\
Carbon monoxide & $14-23 \mathrm{mg}$ \\
Water & $7-12 \mathrm{mg}$ \\
Argon & $5 \mathrm{mg}$ \\
Methane & $1,0-2,0 \mathrm{mg}$ \\
Hydrogen & $0,5-1,0 \mathrm{mg}$ \\
Acetaldehyde & $400-1400 \mu \mathrm{g}$ \\
Nitrogen Oxide & $100-680 \mu \mathrm{g}$ \\
Acetone & $100-650 \mu \mathrm{g}$ \\
Formic acid & $200-600 \mu \mathrm{g}$ \\
Hydrogen cyanide & $400-500 \mu \mathrm{g}$ \\
Propionic acid & $100-300 \mu \mathrm{g}$ \\
Acetonitrile & $100-150 \mu \mathrm{g}$ \\
Pyridine & $20-200 \mu \mathrm{g}$ \\
Acrolein & $60-140 \mu \mathrm{g}$ \\
Ammonia & $10-130 \mu \mathrm{g}$ \\
Formaldehyde & $20-100 \mu \mathrm{g}$ \\
Methanol & $80-100 \mu \mathrm{g}$ \\
\hline
\end{tabular}

\section{General Disease Manifestations Due to Smoking}

Smoking can increase the risk of various diseases. The ratio of smokingrelated conditions compared to nonsmokers (relative risk) is higher at a young age, especially in types of stroke and coronary artery disease. ${ }^{[14]}$ Common diseases often caused by smoking are described in Table 3. From 1965-2014, more than 20 million Americans died due to chronic conditions caused by smoking or as passive smokers, and complications due to smoking during pregnancy (Table 4).

The mechanism of chemical compounds in cigarettes in causing various side effects is a series of multiple stages. Toxic compounds and free radicals in cigarettes can trigger oxidative stress, inflammation to DNA damage that can trigger cancer. These chemical compounds can be taken by the body from the lungs and circulated in the bloodstream to reach almost the entire body. ${ }^{[6]}$
- Smoking and cancer

Smoking is the most significant risk factor for cancer triggers due to $30 \%$ of deaths in cancer patients. ${ }^{[3]}$ Various carcinogenic substances found in cigarettes. This carcinogenic substance can bind to DNA, causing mutations. If the body cannot repair this mutation, it will become cells that grow out of control and become cancerous. ${ }^{[6]}$

These substances in cigarettes also induce mutations in $\mathrm{p} 53$ protein. ${ }^{[3]}$ This p53 protein plays an essential role in regulating cell division and death. Mutations in this protein will cause uncontrolled cell growth that triggers cancer. The nicotine content can influence the occurrence of disease by activating angiogenesis, cell growth, and invasion of cancer cells. ${ }^{[15]}$

- Smoking and lung

Cigarette smoke can invite cytotoxic cells and inflammatory cells to trigger a pro-inflammatory effect on 
Table 3. The relative risk of illness due to smoking ${ }^{[14]}$

\begin{tabular}{lll}
\hline \multicolumn{1}{c}{ Diseases } & \multicolumn{2}{c}{ Smokers } \\
\cline { 2 - 3 } Coronary heart disease & Males & Females \\
$\quad$ Age 35-64 & 2.8 & 3.1 \\
$\quad$ Age $\geq 65$ & 1.5 & 1.6 \\
\hline Cerebrovascular disease & & \\
$\quad$ Age 35-64 & 3.3 & 4 \\
$\quad$ Age $\geq 65$ & 1.6 & 1.5 \\
\hline Aortic aneurysm & 6.2 & 7.1 \\
\hline Cancer & & \\
Lung & 23.3 & 12.7 \\
$\quad$ Larynx & 14.6 & 13 \\
$\quad$ Lip, oral cavity, pharynx & 10.9 & 5.1 \\
$\quad$ Esophagus & 6.8 & 7.8 \\
Bladder & 3.3 & 2.2 \\
$\quad$ Kidney & 2.7 & 1.3 \\
$\quad$ Pancreas & 2.3 & 2.3 \\
$\quad$ Stomach & 2 & 1.4 \\
$\quad$ Liver & 1.7 & 1.7 \\
$\quad$ Colorectal & 1.2 & 1.2 \\
$\quad$ Cervix & & 1.6 \\
Acute myeloid leukemia & 1.4 & 1.4 \\
\hline Sudden infant death syndrome & & 2.3 \\
\hline Infant respiratory distress syndrome & & 1.3 \\
\hline Low birth weight at delivery & & 1.8 \\
\hline
\end{tabular}

Table 4. Total death caused by smoking and exposure to secondhand smoke (1965-2014) ${ }^{[6]}$

\begin{tabular}{ll}
\hline \multicolumn{1}{c}{ Cause of death } & \multicolumn{1}{c}{ Total } \\
\hline Cancer & 6.587 .000 \\
\hline Metabolic and cardiovascular diseases & 7.787 .000 \\
\hline Pulmonary diseases & 3.804 .000 \\
\hline Perinatal conditions & 108.000 \\
\hline Lung cancer in secondhand smoke & 263.000 \\
\hline Coronary heart disease in secondhand smoke & 2.194 .000 \\
\hline
\end{tabular}

nasal epithelial cells, which will increase the production of Reactive Oxygen Species (ROS), Toll-like Receptor-4 (TLR-4), lipopolysaccharides and IL-17A synthesis. Moreover, cigarette smoke causes mucous hypersecretion so that the mucus cleaning process will be disrupted. ${ }^{[17]}$ Smoking decreases immunoglobulin levels in the circulation, decreases $\mathrm{CD}^{+}$ lymphocytes, and decreases phagocyte activity. This process makes smokers become more easily infected. This immunological disorder will recover within six weeks when smokers stop smoking. [3]

- Smoking and cardiovascular

Cigarettes have the property to cause inflammation. Smoking is associated with an increased risk of atherosclerotic plaque. This plaque formation is characterized by an inflammatory reaction and an increase 
in the expression of matrix metalloproteinases. The proinflammatory effect occurs in not only an active smoker but also a passive smoker. ${ }^{[16]}$

- Smoking and pregnancy

The content of cigarettes can harm the fetus. Smoking habits during pregnancy are associated with the incidence of Low Birth Weight (LBW). This relates to the carbon monoxide (CO) due to the cigarette burning process, which can bind strongly to hemoglobin. A strong bond of $\mathrm{CO}$ with hemoglobin will reduce oxygen transport to the fetus, causing hypoxia in the fetus and LBW. ${ }^{[6,18]}$ Also, smoking during pregnancy is a risk factor for ectopic pregnancy. The content of cotinine (active nicotine metabolite) increases the expression of prokinetic (PROKR1) in the fallopian tubes. This process disrupts fallopian contractility and triggers ectopic pregnancy. ${ }^{[19]}$

\section{Tips for Quitting Smoking}

Quitting smoking is not easy to do for smokers because nicotine addiction is one of the obstacles to quitting smoking. Quitting smoking is not impossible. Here are the ways you can stop smoking. ${ }^{20]}$

a. Strong inner determination. Consider first to make a list of reasons to stop smoking to sustain the determination

b. Think positive, and be sure to quit smoking successfully. Give a reward to yourself when the money is usually used for cigarettes and can now be used to buy favorite things

c. Set a target time. Never immediately stop smoking. Try to reduce smoking habits slowly

d. Give support to stop smoking, especially from the smoker's family and friends

e. Look for activities to keep yourself busy. Activities such as worship, exercise, work can reduce the desire to smoke f. Visit smoke-free places such as houses of worship, libraries or other places

g. Look for a substitute for smoking like gum, with the consumption of gum is expected to forget the smoking habit

h. Busy after eating. Most smokers after eating will start smoking again, so when you finish eating, try to busy yourself to forget about smoking

i. Consult a doctor. The doctor will prescribe drugs that can replace the effects of opium from nicotine to reduce tobacco frequently. Currently, the medications used to help stop smoking are nicotine, bupropion, and varenicline. $^{[3]}$

When smoking is stopped, the body will start a toxic disposal response and improve bodily functions. The effects of smoking cessation can be seen in Table 5 . 
Table 5. Benefits of quitting smoking ${ }^{[21]}$

\begin{tabular}{ll}
\hline Start to stop smoking & \multicolumn{1}{c}{ Benefits } \\
\hline 20 minute & Blood pressure, heart rate and peripheral blood flow improve \\
\hline 12 hours & $\begin{array}{l}\text { Almost all nicotine in the body has been metabolized } \\
\text { The level of carbon monoxide in the blood returns to normal }\end{array}$ \\
\hline $24-48$ hours & $\begin{array}{l}\text { Nicotine begins to be eliminated from the body. The taste and } \\
\text { smell function starts to improve }\end{array}$ \\
\hline 5 days & $\begin{array}{l}\text { Most of the nicotine metabolites in the body are gone. } \\
\text { Taste/taste and odor function is much better }\end{array}$ \\
\hline $2-6$ weeks & $\begin{array}{l}\text { The risk of infection in a post-surgical wound is reduced } \\
\text { Ciliary airway function and pulmonary function improve } \\
\text { Shortness of breath and coughing are reduced }\end{array}$ \\
\hline 1 year & $\begin{array}{l}\text { The risk of coronary heart disease is reduced by half } \\
\text { compared with people who continue to smoke }\end{array}$ \\
\hline 5 years & $\begin{array}{l}\text { The risk of stroke decreases at the same level as people who } \\
\text { have never smoked }\end{array}$ \\
\hline 10 years & $\begin{array}{l}\text { All causes of mortality and the risk of coronary heart disease } \\
\text { decrease at the same level as people who have never smoked }\end{array}$ \\
\hline
\end{tabular}

\section{CONCLUSION}

Until now, smoking is one of the toughest challenges in the world of health. Smoking is a risk factor from various diseases to cancer. This is due to the different chemicals contained in cigarettes that endanger health. Stopping smoking is not only saving yourself but also protecting people around smokers.

\section{REFERENCES}

[1] World Health Organization. Tobacco [Internet]. Geneva: World Health Organization; 2019 May [cited 2020 Jan 04]; Available from: https://www.who.int/newsroom/fact-sheets/detail/tobacco

[2] Kementerian Kesehatan Republik Indonesia. Hasil Utama RISKESDAS 2018. Jakarta: Kementerian Kesehatan Republik Indonesia; 2018.

[3] Benowitz NL, Brunetta PG. Smoking hazards and cessation. In: Broaddus VC, Mason RJ, Ernst JD, King TE Jr, Lazarus SC, Murray JF, et al., editors. Murray \& Nadel's textbook of respiratory medicine. $6^{\text {th }}$ ed. Philadelphia: Elsevier Saunders; 2016. p. 807-13
[4] Centers for Disease Control and Prevention. Health effects of cigarette smoking [Internet]. Atlanta, GA: Centers for Disease Control and Prevention; 2020 Apr [cited 2020 Jan 06]. Available from: https://www.cdc.gov/tobacco/data_st atistics/fact_sheets/health_effects/eff ects_cig_smoking/index.htm

[5] World Health Organization. Monitoring tobacco use and prevention policies. Geneva: WHO; 2017.

[6] Onor IO, Stirling DL, Williams SR, Bediako D, Borghol A, Harris MB, et al. Clinical effects of cigarette smoking: epidemiologic impact and review of pharmacotherapy options. Int J Environ Res Public Health. 2017;14(10):1147. doi: 10.3390/ijerph14101147

[7] Jha P, Ramasundarahettige C, Landsman V, Rostron B, Thun M, Anderson RN, et al. 21 ${ }^{\text {st }}$-Century hazards of smoking and benefits of cessation in the United States. N Engl J Med. 2013;368:341-50. doi: 10.1056/NEJMsa1211128

[8] Kementerian Koordinator Bidang Pembangunan Manusia dan Kebudayaan. Pemerintah Indonesia 
perkuat komitmen penanggulangan tembakau [Internet]. Jakarta: Kementerian Koordinator Bidang Pembangunan Manusia dan Kebudayaan; 2019 Sep [cited 2020 Jan 07]. Available from: https://www.kemenkopmk.go.id/arti $\mathrm{kel} /$ pemerintah-indonesia-perkuatkomitmen-penanggulangantembakau

[9] Rodgman A, Perfetti TA. The composition of cigarette smoke: a catalogue of the polycyclic aromatic hydrocarbons. Beiträge zur Tabakforchung. 2006;22(1):13-69.

[10] U.S. Department of Health and Human Services. How Tobacco Smoke Causes Disease: The Biology and Behavioral Basis for Smoking Attributable Disease: A Report of the Surgeon General. Atlanta, GA: U.S. Department of Health and Human Services, Centers for Diseases Control and Prevention, National Center for Chronic Disease Prevention and Health Promotion, Office on Smoking and Health; 2010.

[11] National Cancer Institute. Harms of Cigarette Smoking and Health Benefits of Quitting [Internet]; 2017 Dec [cited 2020 Jan 09]. Available from: https://www.cancer.gov/aboutcancer/causesprevention/risk/tobacco/cessationfact-sheet\#r2

[12] Tirtosastro S, Murdiyati AS. Kandungan kimia tembakau dan rokok. Buletin Tanaman Tembakau, Serat \& Minyak Industri. 2010;2(1):33-43.

[13] Connecticut State Department of Public Health. Tobacco smoke - the dangers of secondhand smoke [Internet]. [cited 2020 Jan 10]. Available from: https://portal.ct.gov/DPH/Health-

Education-Management-Surveilance/Asthma/Tobacco-Smoke

[14] Burns DM. Nicotine addiction. In: Kasper DL, Hauser SL, Jameson JL,
Fauci AS, Longo DL, Loscalzo J, editors. Harrison's principle of internal medicine. $19^{\text {th }}$ ed. New York: McGraw-Hill Education; 2015. p. 2729-32

[15] Xue J, Yang S, Seng S. Mechanism of cancer induction by tobacco-spesific NNK and NNN. Cancers (Basel). 2014;6(2):1138-56. doi: 10.3390/cancers6021138

[16] Messner B, Bernhard D. Smoking and cardiovascular disease: mechanism of endothelial dysfunction and early atherogenesis. Arterioscler Thromb Vasc Biol. 2014;34(3):509-15. doi: 10.1161/ATVBAHA.113.300156

[17] Strzelak A, Ratajczak A, Adamiec A and Feleszko W. Tobacco smoke induces and alters immune responses in the lung trigerring inflammation, allergy, asthma and other lung diseases: a mechanistic review. Int $\mathbf{J}$ Environ Res Public Health. 2018;15(5):1033.

[18] Banderali G, Martelli A, Landi M, Moretti F, Betti F, Radaelli G, et al. Short and long term health effects of parental tobacco smoking during pregnancy and lactation: a descriptive review. J Transl Med. 2015;13:327. doi: 10.1186/s12967-015-0690-y

[19] Horne AW, Brown JK, NioKobayashi J, Abidin HB, Adin ZE, Boswell L, et al. The association between smoking and ectopic pregnancy: why nicotine is bad for your fallopian tube. PloS One. 2014;9(2):e89400. doi: 10.1371/journal.pone. 0089400

[20] Departemen Kesehatan Republik Indonesia. Inilah 15 tips cara berhenti merokok yang efektif [Internet]. Jakarta: Departemen Kesehatan Republik Indonesia; 2015 Nov [cited 2020 Jan 11]. Available from: https://www.kemkes.go.id/developm ent/site/layanankesehatan/index.php?view=print\&ci $\mathrm{d}=1-15112500016 \& \mathrm{id}=$ inilah-15- 
tips-cara-berhenti-merokok-yang-

efektif-

[21] Direktorat Pencegahan dan

Pengendalian Penyakit Tidak

Menular. Manfaat berhenti merokok

[Internet]. Jakarta: Direktorat

Pencegahan dan Pengendalian

Penyakit Tidak Menular; 2017 May

[cited 2020 Jan 12]. Available from:

https://www.p2ptm.kemkes.go.id/ke

giatan-p2ptm/subdit-penyakit-paru-

kronik-dan-gangguan-

imunologi/manfaat-berhenti-

merokok-faq 